\title{
EFFECT OF PARTIAL REPLACEMENT OF SOYBEAN MEAL WITH OPTIGEN ON THE PERFORMANCE OF GROWING LAMBS
}

\author{
MAHMOUD, S.A. ${ }^{1}$; M.M. BENDARY ${ }^{2}$; N.M. EWEEDAH ${ }^{1}$ and A.A. SROUR ${ }^{3}$
}

1. Department of Animal Production, Faculty of Agriculture, Kafrelsheikh University.

2. Animal Production Research Institute, Agricultural Research Center.

3. Production Sector, Agricultural Research Center.

(Manuscript received 18 May 2017)

\begin{abstract}
$\mathrm{T}$ he objective of this study was to evaluate the effect of partial replacement of soybean meal (SBM) as traditional source of protein with optigen as slow-release urea in rations of growing lambs on growth performance, ruminal fermentation, digestibility and economical efficiency. Twenty four Rahmani lambs with average initial live body weight (LBW) of $25.97 \pm 0.07 \mathrm{~kg}$ were divided into three similar groups ( 8 in each). All lambs were fed rations composed $2 \%$ of their LBW concentrate feed mixture (CFM) plus $1 \%$ of LBW clover hay (CH). Lambs in the control group were fed the control ration without optigen $\left(R_{1}\right)$, while in the other groups, optigen was supplemented at levels of 0.9 and $1.8 \%$ of CFM instead of 15.81 and $31.07 \%$ of the protein content of CFM used for $R_{2}$ and $R_{3}$, respectively. Chemical composition of tested rations were nearly similar in their contents of all nutrients. The highest $(P<0.05)$ digestibility of all nutrients and nutritive values were recorded for $R 2$, while control ration $\left(R_{1}\right)$ showed the lowest values and R3 achieved intermediated values. No significant differences were observed among tested rations and sampling times for ruminal $\mathrm{pH}$ values, expect $\mathrm{R}_{2}$ recorded significant difference between sampling time. While TVFA's and $\mathrm{NH}_{3}-\mathrm{N}$ concentrations were significantly $(\mathrm{P}<0.05)$ differ among the different rations and sampling times. The DMI was nearly similar for different groups, while TDN, DCP and DE intake were significantly higher $(P<0.05)$ in $2^{\text {nd }}$ group compared with control, whereas $3^{\text {rd }}$ group recorded intermediate values. Final body weight, total and daily weight gain were significantly higher $(P<0.05)$ with $R_{2}$ compared to $R_{1}$ and $R_{3}$. However, feed conversion ratio did not significantly difference for the different rations. Rations contained different levels of optigen achieved significantly $(P<0.05)$ higher economic efficiency than control ration. It could be concluded that the inclusion of optigen at level of $0.9 \%$ in CFM in the diet of growing lambs were more economical efficiency and can be used to replace a part of soybean meal without any adverse effect on their performance.
\end{abstract}

Keywords: Optigen, Rahmani lambs, growth performance and digestibility.

\section{INTRODUCTION}

Non-protein nitrogen compounds are relatively cheap compared to protein feed sources like soybean meal (SBM); they are a proper alternative to natural plant 
protein sources and are more affordable per unit N. From non-protein nitrogen compounds, urea has found the wide application in ruminant rations (Varlyakov et al., 2015 and Mentz et al., 2015). Incorporation of one unit of urea in ruminant diet can replace five units of soybean meal (Khan et al., 2015). However, the utilization of urea as an NPN source is limited because the rapid conversion of urea to ammonia may often exceed the ability of rumen bacteria to utilize the rumen $\mathrm{NH}_{3}-\mathrm{N}$ resulting in a loss of $\mathrm{N}$ for synthesis of microbial protein (Galo et al., 2003). Also, this led to accumulation and escape of ammonia from rumen wall causing toxicity (Satter and Roffler, 1975). However, overcome this limitation and reduce risks of urea toxicity in ruminants, various options have been evaluated over the years such as creating slowrelease $\mathrm{N}$ sources (Mentz et al., 2015). These technologies are used to improve synchrony between available energy and $\mathrm{N}$ in the rumen to maximize microbial protein synthesis and minimize the risk of $\mathrm{N}$ source toxicity (Harrison and Karnezos, 2005). The aim of using a slow-release $\mathrm{N}$ source is to provide a slow release of $\mathrm{N}$ over the day round and meet the $\mathrm{N}$ requirements of rumen bacteria when rumen $\mathrm{NH}_{3}-\mathrm{N}$ levels are expected to be low after the ingestion of urea. Providing a sustained level of $\mathrm{N}$ increased utilization efficiency and microbial protein production (Harrison and Karnezos, 2005). Also, provide a slow hydrolysis of these compounds with gradual release of ammonia in the fore-stomach and creating favorable conditions for replication of photolytic microbial populations (Varlyakov et al., 2015).

Recently, the interest towards protected proteins in ruminant rations has increased. They are used to avoid the full degradation of proteins in the rumen and to reduce the ammonia levels in rumin liquor. At the same time, protected proteins are mainly degraded in the abomasum and small intestine, where their utilization by the body is more complete. A number of commercial products containing protected proteins are marketed on global scale. One of them is optigen is a source of specifically protected NPN with indirectly controlled release in the fore-stomach of ruminants it is gradually degraded, providing steady and valuable source of nonprotein nitrogen. It is specially designed for using it during formulation of ruminant rations with the intention to optimize the costs for protein ingredients. The active substance of optigen is covered with a biodegradable film, which permits gradual nitrogen release. The formulation is an excellent source of nitrogen concentrate, which behaves totally differently from urea and could improve the function of the rumen (Varlyakov et al., 2015). However, the consequences of replacing sources of true protein with slow release urea (SRU) in the ruminant rations remain unclear. Therefore, the objective of this study was to investigate the effect of substitution a part of soybean meal by Optigen $\AA$ as slow release urea (SRU) products in growing 
Rahmani lambs rations on their growth performance, ruminal fermentation, digestibility and economic efficiency.

\section{MATERIALS AND METHODS}

\section{Experimental lambs and rations:}

Twenty four Rahmani lambs averaged $25.97 \pm 0.07 \mathrm{~kg}$ of live body weight (LBW) and 4 months old were divided into 3 similar groups (8 in each) according to LBW and age used in growth trial for 120 days. All lambs were fed rations contained $2 \%$ of their LBW concentrate feed mixture (CFM) plus $1 \%$ of LBW clover hay $(\mathrm{CH})$. Lambs in the $1^{\text {st }}$ group were fed control ration without optigen (R1), while in the $2^{\text {nd }}$ and $3^{\text {rd }}$ groups, optigen was supplemented at levels of 0.9 and $1.8 \%$ in the CFM instead of 15.81 and $31.07 \%$ of the protein content of CFM for $R_{2}$ and $R_{3}$, respectively. Agriculture sulfur was added with other experimental ingredients during preparing the $2^{\text {nd }}$ and $3^{\text {rd }}$ CFM and the ratio between Agriculture sulfur /optigen supplementation was $1 \mathrm{~g}$ sulfur/10 $\mathrm{g}$ optigen. The formulation of the different experimental CFM is illustrated in Table (1).

Table 1. Formulation of the experimental CFM\% as fed basis.

\begin{tabular}{|l|c|c|c|}
\hline \multicolumn{1}{|c|}{ Item } & CFM1 & CFM2 & CFM3 \\
\hline Yellow corn grain & 54.0 & 60.0 & 66.2 \\
Wheat bran & 25.0 & 25.0 & 25.0 \\
Soybean meal & 17.5 & 10.6 & 3.5 \\
Optigen & 0.0 & 0.9 & 1.8 \\
Sodium chloride & 1.6 & 1.6 & 1.6 \\
Carbonate calcium & 1.6 & 1.6 & 1.6 \\
Mineral mixtures* & 0.3 & 0.3 & 0.3 \\
Agriculture sulfur (g/ton CFM) & - & 90 & 180 \\
\hline
\end{tabular}

* Mineral mixtures contained $50000 \mathrm{mg}$ manganese, $60000 \mathrm{mg}$ zinc, $30000 \mathrm{mg}$ iron, $10000 \mathrm{mg}$ copper, 2500 $\mathrm{mg}$ iodine, $200 \mathrm{mg}$ selenium, $500 \mathrm{mg}$ cobalt and $\mathrm{CaCO}_{3}$ carrier add to $3 \mathrm{~kg}$. It is maxed with one ton of CFM.

\section{Feeding system:}

Lambs were weighed for three consecutive days at beginning of experiment and biweekly thereafter before the morning feeding and after fasting for 16 hours. Meanwhile, offered rations were adjusted biweekly according to body weight changes. Lambs were fed in groups, CFM was offered twice daily at 8 a.m. and 4 p.m., while $\mathrm{CH}$ once daily at 9 a.m. Drinking water was allowed freely all the day around. Orts, if any, were collected just before offering the next day's feed. Feed intake and live body weight were recorded to calculate the daily body weight gain, feed conversion ratio and economic efficiency. 


\section{Digestion trials:}

Three digestibility trials were conducted using 3 lambs from each group at the middle of feeding trial to determine nutrients digestibility coefficients and the nutritive values of tested rations. Each trial consisted of 15 days as preliminary period followed by 7 days as collection period. Lambs were fed individually their allowances and managed according to experimental assignment of each group. Fecal rectum samples were collected from each animal twice daily with 12 hours interval. Samples of tested feedstuffs and feces were dried at $60{ }^{\circ} \mathrm{C}$ for 48 hours. Then, ground, composted and representative samples were analyzed according to AOAC (2012). Acid insoluble ash (AIA) technique was used as a neutral marker as described by Van Keulen and Young (1977). Nutrient digestibility coefficients were calculated by the equation stated by Scheinder and Flatt (1975). Total digestible nutrients (TDN) and digestibility crude protein (DCP) were calculated according to the classic formula of McDonald et al. (1995). The DE value was calculated from the equation stated by (NRC, 1989).

\section{Rumen liquor samples:}

Rumen liquor samples were collected before starting digestibility trials from each lamb at three times, in the morning before feeding (zero time), 3 and 6 hours after feeding using rubber stomach tube. Rumen liquor was strained through double layer of cheese cloth. Rumen pH was determined immediately using Orian 680 digital $\mathrm{pH}$ meter. Ammonia nitrogen $\left(\mathrm{NH}_{3}-\mathrm{N}\right)$ concentration where determined using magnesium oxide according to AOAC (2012) and TVFA's concentration was determined by a steam distillation method according to Warner (1964).

\section{Feed conversion ratio:}

Feed conversion ratio was calculated and expressed in terms of $\mathrm{kg} \mathrm{DM,} \mathrm{DCP}$ and Mcal DE required for producing one $\mathrm{kg}$ of live weight gain (LWG).

\section{Economic efficiency:}

Economic efficiency was calculated as the ratio between the income (price of daily weight gain) and cost of daily feed consumed. Prices in Egyptian pounds during $1^{\text {st }}$ quarter 2016 were CFM1 (3.13 LE/kg), CFM2 (2.90 LE/kg), CFM3 (2.66 LE/kg), clover hay (1.25 LE/kg), optigen (20 LE / kg) and live weight gain (40 LE/kg).

\section{Statistical analysis:}

The data were analyzed using general linear models procedure adapted by IBM SPSS Statistics 22 (2014) for user's guide with one-way ANOVA. Significant differences in the mean values among dietary treatments were analyzed by Duncan's within SPSS program set at the level of significance $P<0.05$. 


\section{RESULTS AND DISCUSSION}

\section{Chemical composition:}

The different tested CFM was approximately similar in their contents of OM, $\mathrm{CP}, \mathrm{EE}, \mathrm{CF}, \mathrm{NFE}$ and ash. Also, the corresponding composition of experimental rations were isocaloric and isonitrogenous and nearly similar in their contents of all nutrients being $13.84-14.20 \% \mathrm{CP}, 3.35-3.57 \% \mathrm{EE}, 15.11-16.55 \% \mathrm{CF}$ and $58.94-59.33 \%$ NFE (Table2).

Table 2. Chemical composition of experimental CFM, clover hay and experimental rations.

\begin{tabular}{|c|c|c|c|c|c|c|c|}
\hline \multirow{2}{*}{ Item } & \multirow{2}{*}{ DM \% } & \multicolumn{6}{|c|}{ Composition $\%$ on DM basis } \\
\hline & & $\mathrm{OM}$ & $\mathrm{CP}$ & EE & $\mathrm{CF}$ & NFE & Ash \\
\hline $1^{\text {st }}$ CFM & 90.60 & 94.70 & 14.34 & 3.41 & 10.82 & 66.13 & 5.30 \\
\hline $2^{\text {nd }} C F M$ & 91.12 & 94.18 & 14.57 & 3.60 & 9.55 & 66.46 & 5.82 \\
\hline $3^{\text {rd }}$ CFM & 90.91 & 94.06 & 14.83 & 3.71 & 8.91 & 66.61 & 5.94 \\
\hline Clover hay & 90.75 & 87.64 & 12.60 & 3.20 & 30.85 & 40.99 & 12.36 \\
\hline \multicolumn{8}{|c|}{ Calculated composition of experimental rations: } \\
\hline $\mathrm{R}_{1}$ & 90.64 & 92.68 & 13.84 & 3.35 & 16.55 & 58.94 & 7.32 \\
\hline $\mathrm{R}_{2}$ & 91.02 & 92.33 & 14.01 & 3.49 & 15.62 & 59.25 & 7.67 \\
\hline $\mathrm{R}_{3}$ & 90.86 & 92.24 & 14.20 & 3.57 & 15.15 & 59.33 & 7.76 \\
\hline
\end{tabular}

\section{Digestibility coefficients and nutritive values:}

Nutrient digestibility coefficients of tested rations (Table3) showed that optigen supplementation significantly $(P<0.05)$ increased digestibility coefficients of all nutrients in $R_{2}$ and $R_{3}$ compared to control ration ( $\left.R 1\right)$. Meantime, $R_{2}$ recorded significantly $(P<0.05)$ the highest digestibility coefficients of $D M, O M, C P, E E$ and NFE and $R_{3}$ had the highest CF digestibility; however, $R_{1}$ recorded the lowest digestibility coefficients of all nutrients. Improvement of digestibility coefficients of the $2^{\text {nd }}$ and $3^{\text {rd }}$ rations may be attributed to inclusion of optigen at the levels of 0.9 and $1.8 \%$ which can stimulate anaerobic fermentation of DM that improve the utilization efficiency of nutrients and directed role to improve digestion in abomasum. These results are confirmed with the results of Galina et al. (2003) who reported that nutrients digestibility improved in kids fed diet contained slow-release urea (SRU) and suggested that these improvement was due to elevation of rumen $\mathrm{pH}$ and augmentation of fiber fermentation at ruminal bacteria through offering of non-protein $\mathrm{N}$, essential amino acids, extra sulphur, phosphorus along with continuous ammonia supply in the rumen. Eweedah et al. (2016) stated that digestibility coefficients by 
Holistien steers were higher with rations containing optigen compared with the control group. The lower values of CF digestibility may be due to that the ruminal $\mathrm{pH}$ values recorded with feeding all tested rations were nearly consistently maintained below 6 expect in the $2^{\text {nd }}$ ration after 3hours of sampling ruminal $\mathrm{pH}$ value remained below 6.2 Table (4) which have a negative effect on fiber digestion as stated by Mould et al. (1983).

There were significant differences $(P<0.05)$ in TDN, DCP and DE values among the different experimental groups, whereas $\mathrm{R}_{2}$ achieved the highest TDN, DCP and $D E$ values while $R_{1}$ recorded the lowest values, meantime $R_{3}$ appeared intermediate values (Table3). The improvement in nutritive values of $R_{2}$ and $R_{3}$ may be due to that optigen prolong microbial utilization of additional $\mathrm{N}$ sources during ruminal fermentation. These results are in agreement with those obtained by Eweedah et al. (2016) who concluded that the improvement of nutritive values of steers rations can be achieved by the partial replacement of soybean meal with optigen as slow-release urea (SRU).

Table 3. Digestibility coefficients and nutritive values of tested rations.

\begin{tabular}{|l|c|c|c|c|}
\hline \multirow{2}{*}{ Item } & \multicolumn{3}{|c|}{ Experimental rations } & \multirow{2}{*}{ MSE } \\
\cline { 2 - 4 } & R1 & R2 & R3 & \\
\hline \multirow{2}{*}{ Digestibility coefficients \%: } & $64.93^{\mathrm{a}}$ & $63.21^{\mathrm{b}}$ & 1.00 \\
\hline DM & $58.44^{\mathrm{c}}$ & $69.45^{\mathrm{a}}$ & $67.71^{\mathrm{b}}$ & 0.90 \\
OM & $63.61^{\mathrm{c}}$ & $75.18^{\mathrm{a}}$ & $72.19^{\mathrm{b}}$ & 0.77 \\
CP & $70.20^{\mathrm{c}}$ & $74.35^{\mathrm{a}}$ & $72.89^{\mathrm{a}}$ & 1.08 \\
EE & $67.67^{\mathrm{b}}$ & $47.32^{\mathrm{a}}$ & $48.32^{\mathrm{a}}$ & 1.29 \\
CF & $41.33^{\mathrm{b}}$ & $73.32^{\mathrm{a}}$ & $69.65^{\mathrm{b}}$ & 0.80 \\
NFE & $68.35^{\mathrm{b}}$ & & \\
\hline Nutritive values: & \multicolumn{5}{|c|}{} & 0.81 \\
\hline TDN, \% & $61.91^{\mathrm{c}}$ & $67.12^{\mathrm{a}}$ & $64.73^{\mathrm{b}}$ & 1.00 \\
DCP, \% & $9.73^{\mathrm{b}}$ & $10.36^{\mathrm{a}}$ & $10.29^{\mathrm{a}}$ & 0.80 \\
DE, Mcal/kg DM & $2.73^{\mathrm{c}}$ & $2.95^{\mathrm{a}}$ & $2.85^{\mathrm{b}}$ & \\
\hline
\end{tabular}

a, b, c: Values in the same row with different superscripts differ significantly $(P<0.05)$.

$\mathrm{DE} \mathrm{Mcal} / \mathrm{kg} \mathrm{DM}=0.04409 \times \mathrm{TDN} \%$ (NRC, 1989).

\section{Rumen liquor parameters:}

The effect of feeding different levels of optigen and sampling time on ruminal liquor parameters of experimental lambs are shown in Table (4). There was no significant difference $(P>0.05)$ between treatments of ruminal $\mathrm{pH}$ values. These results confirmed with the results of Eweedah et al. (2016) who indicated that there was no significant difference in $\mathrm{pH}$ value with using optigen as a replacer to soybean meal in the diet of fattening calves. Present study, cleared ruminal $\mathrm{pH}$ with feeding all tested rations was consistently maintained below $6.0-6.2$. The low pH 
values obtained in the present study could be explained by the high concentrate ratio in the tested rations (70\%). Concerning sampling times clearly indicated that no significant differences between sampling time with feeding $R_{1}$ and $R_{3}$, while rumen $p H$ values $\mathrm{R}_{2}$ recorded significant difference between sampling time. Meantime, rumen $\mathrm{pH}$ was decreased and recorded the lowest values at zero time (5.6-5.9). The reason for this decline in rumen $\mathrm{pH}$ might be due to a combination of decreased $\mathrm{NH}_{3}-\mathrm{N}$ and the high concentration of TVFA's (Table 4).

The comparison among the experimental rations showed that $\mathrm{R}_{3}$ recorded significantly higher $(P<0.05)$ concentrations of TVFA's in rumen liquor at all sampling times compared to $R_{1}$ and $R_{2}$, without significant differences between $R_{1}$ and $R_{2}$ at the different sampling times. Also, overall mean value of the ruminal TVFA's showed significant differences with all sampling time (Table4).

Table 4. Effect of optigen on ruminal liquor parameters of experimental lambs.

\begin{tabular}{|c|c|c|c|c|c|}
\hline Sampling time & $\mathrm{R}_{1}$ & $\mathrm{R}_{2}$ & $\mathrm{R}_{3}$ & $\begin{array}{c}\text { Overall } \\
\text { mean }\end{array}$ & MSE \\
\hline $\mathrm{pH}$ value & & & & & \\
\hline Zero & 5.7 & $5.6^{\mathrm{B}}$ & 5.9 & 5.7 & 0.11 \\
\hline 3 hrs & 5.9 & $6.0^{\mathrm{AB}}$ & 5.7 & 5.9 & 0.10 \\
\hline 6 hrs & 5.9 & $6.2^{\mathrm{A}}$ & 6.0 & 6.0 & 0.13 \\
\hline Overall mean & 5.8 & 6.0 & 5.9 & 5.9 & 0.07 \\
\hline SEM & 0.13 & 0.11 & 0.12 & 0.07 & \\
\hline TVFA's (mq/100 ml) & & & & & $14.4 \mathrm{~A}$ \\
\hline Zero & $13.3^{\mathrm{bA}}$ & $13.1^{\mathrm{bA}}$ & $16.8^{\mathrm{aA}}$ & 0.71 \\
\hline 3 hrs & $11.8^{\mathrm{bAB}}$ & $12.3^{\mathrm{bA}}$ & $15.6^{\mathrm{aAB}}$ & $13.2 \mathrm{AB}$ & 0.64 \\
\hline 6 hrs & $10.4^{\mathrm{bB}}$ & $10.0^{\mathrm{bB}}$ & $13.6^{\mathrm{aB}}$ & $11.3 \mathrm{~B}$ & 0.75 \\
\hline Overall mean & $11.8^{\mathrm{b}}$ & $11.8^{\mathrm{b}}$ & $15.3^{\mathrm{a}}$ & 13.0 & 0.48 \\
\hline SEM & 0.58 & 0.56 & 0.63 & 0.48 & \\
\hline $\mathrm{NH}_{3}-\mathrm{N}(\mathrm{mg} / 100 \mathrm{ml})$ & & & & & \\
\hline Zero & $33.7^{\mathrm{cA}}$ & $35.6^{\mathrm{aB}}$ & $34.6^{\mathrm{bA}}$ & 34.6 & 0.29 \\
\hline 3 hrs & $33.6^{\mathrm{cA}}$ & $35.5^{\mathrm{aB}}$ & $34.9^{\mathrm{bA}}$ & 34.7 & 0.29 \\
\hline 6 hrs & $33.1^{\mathrm{cB}}$ & $35.8^{\mathrm{aA}}$ & $34.1^{\mathrm{bB}}$ & 34.3 & 0.41 \\
\hline Overall mean & $33.5^{\mathrm{c}}$ & $35.7^{\mathrm{a}}$ & $34.5^{\mathrm{b}}$ & 34.5 & 0.19 \\
\hline SEM & 0.11 & 0.05 & 0.15 & 0.19 & \\
\hline
\end{tabular}

$a, b, c:$ Values in the same row with different superscripts differ significantly $(P<0.05)$.

$A, B$ : Values in the same column with different superscripts differ significantly $(P<0.05)$.

The lowest values of TVFA's were observed at 6 hour post feeding for all tested rations, while the highest values were recorded at zero time. These results are in opposite trend with those of $\mathrm{pH}$ values.

Results of ruminal ammonia-nitrogen in Table (4) showed that lambs fed $R_{2}$ achieved significantly $(P<0.05)$ the highest ruminal ammonia concentration at zero time, 3 and 6 hours along with overall means, however, $\mathrm{R}_{1}$ had the lowest values. Meantime, $\mathrm{R}_{3}$ recorded intermediate values at all 
sampling times, with significant differences $(P<0.05)$ among the tested rations.

Concerning the effect of sampling time, the lowest values of $\mathrm{NH}_{3}-\mathrm{N}$ were detected after 6 hours post feeding. Ruminal ammonia-N concentration in the present study was within the normal range obtained by Church (1976), being from 10 to 45 $\mathrm{mg} / \mathrm{dl}$ depending on chemical composition of the ration, time of sampling and method of analysis.

\section{Feed intake:}

Lambs were group feed, so comparisons regarding feed intakes of all nutrients are made on a relative rather than on a statistical basis. Average values of DM1 for all experimental lambs in all groups were nearly similar (Table5). This due that all lambs fed restricted quantities from CFM and $\mathrm{CH}$ ( 2 and $1 \%$ of LBW, respectively). Also, results revealed that the average daily TDN, DE and DCP intakes for different treatments appeared to be more affected by nutritive values of tested rations. It was noticeable that lambs fed $R_{2}$ consumed more TDN, DCP and DE compared with $R_{1}$. Meantime, lambs fed $R_{3}$ consumed intermediate values of TDN, DCP and DE. These resulted are in the same trend with those of total body weight gain and average daily gain (Table 5).

\section{Growth performance:}

Results of body weight and weight gain of experimental lambs as affected by feeding diet contained different levels of optigen are presented in Table (6). It was noticeable that $R_{2}$ produced the highest $(P<0.05)$ final body weight, total and daily weight gain, while lambs fed R1 and R3 rations achieved the lowest values with insignificant differences. Calculated relative daily body weight gain of lambs fed $R_{2}$ increased significantly by $10.0 \%$ compared to those fed $R_{1}$. The improvement of BWG of experimental lambs fed $R_{2}$ could be attributed to the high contents and intake of TDN, $D C P$ and $D E$ for $R_{2}$ compared with $R_{1}$ and $R_{3}$ (Table 3) which were efficiency metabolized for growth. The present results are supported by Aljabary and Kutaibani (2013) who indicated that, the total and daily weight gain of Awassi lambs were significantly higher $(\mathrm{P}<0.05)$ with feeding urea-molasses blocks compared with those fed on blocks without urea. The same trend was found also by Eweedah et al. (2016) who found that the usage of optigen at 1.35 and $1.85 \%$ on DM basis can replace soybean meal in the diet of fattening calves without any negative effect on growth performance and indicated that the daily gain was significantly higher with feeding optigen compared without optigen (control ration). Also, these result confirmed with the resulted of Pinos- Rodríguez et al. (2010) who reported that optigen at $1 \%$ of DM in replacing to soybean meal in the diets of beef steers without any negative effect on growth performance. 
Table 5. Average daily feed intake ( $\mathrm{kg} / \mathrm{head} /$ day) of experimental lambs.

\begin{tabular}{|c|c|c|c|}
\hline \multirow{2}{*}{ Item } & \multicolumn{3}{|c|}{ Experimental rations } \\
\hline & R1 & $\mathrm{R} 2$ & R3 \\
\hline Duration(day) & 120 & 120 & 120 \\
\hline \multicolumn{4}{|c|}{ Average daily fed intake as fed ( $\mathrm{kg} / \mathrm{lamb} /$ day) } \\
\hline $\begin{array}{l}1^{\text {st }} \text { CFM } \\
2^{\text {nd }} C F M \\
3^{\text {rd }} C F M \\
\text { Clover hay }\end{array}$ & $\begin{array}{c}0.824 \\
- \\
- \\
0.329\end{array}$ & $\begin{array}{c}- \\
0.845 \\
- \\
0.335\end{array}$ & $\begin{array}{c}- \\
- \\
0.828 \\
0.329\end{array}$ \\
\hline Total & 1.153 & 1.180 & 1.157 \\
\hline \multicolumn{4}{|c|}{ Average daily fed intake on DM basis (kg/lamb/day) } \\
\hline $\begin{array}{l}1^{\text {st }} \text { CFM } \\
2^{\text {nd }} C F M \\
3^{\text {rd }} C F M \\
\text { Clover hay }\end{array}$ & $\begin{array}{c}0.747 \\
- \\
- \\
0.299\end{array}$ & $\begin{array}{c}- \\
0.770 \\
- \\
0.304\end{array}$ & $\begin{array}{c}- \\
- \\
0.753 \\
0.299\end{array}$ \\
\hline Total DM & 1.046 & 1.074 & 1.052 \\
\hline TDN & 0.648 & 0.719 & 0.681 \\
\hline $\mathrm{CP}$ & 0.145 & 0.148 & 0.150 \\
\hline DCP & 0.102 & 0.111 & 0.108 \\
\hline $\mathrm{DE}$ (M cal/lamb/day) & 2.86 & 3.17 & 3.01 \\
\hline
\end{tabular}

\section{Feed conversion ratio:}

Results of feed conversion ratio (Table 6) did not show any significant $(P>0.05)$ differences between tested rations. These results are supported by PinosRodríguez et al. (2010), who reported that feed efficiency was not affected for beef steers fed diet contain slow-release polymer-coated urea product (CU) at $1.0 \%$ of DM. In contrast, Eweedah et al. (2016) recorded the better values of feed conversion of Holistien steers fed (75 g optigen) compared to those fed control ration without optigen. Wide variations are noticed among reviewed values, which may be due to the differences of SRU levels, basal diet used and plane of nutrition and nutrients balances in tested rations along with species of animals.

\section{Economic efficiency:}

Results of economic efficiency achieved as affected by feeding diet contained 0.9 and $1.8 \%$ optigen (Table 6 ) indicated that the feed cost per $\mathrm{kg}$ gain decreased significantly $(P<0.05)$ with increasing optigen level up to $1.8 \%$. Whereas, the control ration recorded the highest $(P<0.05)$ cost $\left(18.69 \mathrm{LE} / \mathrm{kg}\right.$ gain). Lambs fed $R_{2}$ and $R_{3}$ achieved the best relative economic efficiency with high significant $(P<0.05)$ values (2.45 and 2.50), while the lowest value was recorded with lambs fed $R_{1}$ (2.14). The lowest feed cost $/ \mathrm{kg}$ gain and the best economic efficiency achieved with feeding optigen is due to the low price of $\mathrm{CP}$ unit obtained from optigen compared with soybean meal. One gram of optigen with $256 \%$ CP will give a similar amount of $\mathrm{N}$ as 
that $7.10 \mathrm{~g}$ of soybean meal $53 \% \mathrm{CP}$ on DM basis (Tikofsky and Harrison, 2006). However, inclusion urea or SRU with sheap price compared with the high price of soybean which, decrease the feeding cost of ruminants (Khan et al., 2015). Moreover, Harrison and Karnesos (2005); Tikofsky and Harrison (2006) mentioned that using optigen as NPN reduce ration cost. The same trend was observed by Pinos- Rodríguez et al. (2010) who indicated that animals fed rations contained optigen were more economically efficient than those without optigen. Also, Eweedah et al. (2016) indicated that inclusion of $75 \mathrm{~g}$ optigen in Holistien steers ration improved the income of daily gain. The result of the present study indicated that replacing soybean meal with the high price with optigen as slow release urea in lambs diet improved the digestibility coefficients for all nutrient and nutritive values of tested rations. However lambs fed $R_{2}$ and $R_{3}$ gained 10.0 and $2.0 \%$ more than control ration as well as improved the relative economic efficiency compared with the control group but on contract feed conversion did not show any significant different as the result of using optigen.

Table 6. Growth performance, feed conversion ratio and economic efficiency of growing lambs fed experimental rations.

\begin{tabular}{|c|c|c|c|c|}
\hline \multirow{2}{*}{ Items } & \multicolumn{3}{|c|}{ Experimental group } & \multirow{2}{*}{ MSE } \\
\hline & R1 & R2 & R3 & \\
\hline NO. of animals & 8 & 8 & 8 & \\
\hline Duration of trial(days) & 120 & 120 & 120 & \\
\hline \multicolumn{5}{|l|}{ Growth performance: } \\
\hline Av. Initial live weight $(\mathrm{kg})$ & 25.96 & 25.90 & 26.03 & 0.07 \\
\hline Av. final live weight gain(kg) & $45.10^{\mathrm{b}}$ & $47.00^{\mathrm{a}}$ & $45.60 a^{b}$ & 0.31 \\
\hline Av. total live weight gain $(\mathrm{kg})$ & $19.14^{\mathrm{b}}$ & $21.10^{\mathrm{a}}$ & $19.57^{\mathrm{b}}$ & 0.30 \\
\hline Av. Daily live weight gain(g) & $160^{\mathrm{b}}$ & $176^{\mathrm{a}}$ & $163^{b}$ & 2.52 \\
\hline \multicolumn{5}{|l|}{ Feed conversion: } \\
\hline Kg.DMI/Kg gain & 6. 54 & 6.10 & 6.45 & 0.093 \\
\hline $\mathrm{Kg} . \mathrm{TDN} / \mathrm{Kg}$ gain & 4.05 & 4.09 & 4.18 & 0.057 \\
\hline $\mathrm{Kg} . \mathrm{DCP} / \mathrm{Kg}$ gain & 0.638 & 0.632 & 0.643 & 0.011 \\
\hline DE.Mcal/Kg gain & 17.88 & 18.01 & 18.47 & 0.249 \\
\hline \multicolumn{5}{|l|}{ Economic efficiency } \\
\hline Feed cost/day(LE) ${ }^{a}$ & $2.99 a$ & $2.87^{\mathrm{a}}$ & $2.61^{\mathrm{b}}$ & 0.028 \\
\hline Feed cost/kg gain(LE) & $18.69^{a}$ & $16.31^{\mathrm{b}}$ & $16.01^{b}$ & 0.292 \\
\hline Price of daily gain $(L E)^{b}$ & $6.4^{b}$ & $7.04^{a}$ & $6.52^{b}$ & 0.101 \\
\hline Economic efficiency* & $2.14^{\mathrm{b}}$ & $2.45^{\mathrm{a}}$ & $2.50^{\mathrm{a}}$ & 0.037 \\
\hline
\end{tabular}

$a, b, c$. values in the same row with different superscripts differ significantly $(p<0.05)$

* Economic efficiency $=\mathrm{b} / \mathrm{a}$

\section{CONCLUSION}

It can be recommended that the using of optigen as SRU at levels 0.9 and $1.8 \%$ in the diet of growing lambs were more economical efficiency. Moreover, optigen can be successfully used during formulation ruminant rations, if the cost of 
one unit of optigen less than the prices of 5 units of SBM (44\%) were replaced plus the price of easy fermented carbohydrate (molasses or corn), would be included.

\section{SIGNIFICANT STATEMENT}

Recently in Egypt, conventional protein feed sources such as soybean meal and cotton seed meal tend to increase the animal production costs due to the high and rapid increase of their prices as a result of either their being transported from other regions or being considered a commodity. Thus, the partial replacement of traditional feeds with the high prices (SBM) with NPN sources has become a common practice in the attempt to lower production cost. Incorporation of one unit of urea in ruminant rations can replace five units of soybean meal (Khan et al., 2015). However, rations formulated from NPN sources must efficient and economical, along with offering the performance obtained from conventional rations. Among these NPN sources as SRU is optigen with $256 \%$ CP where one gram of optigen will give a similar amount of $\mathrm{N}$ as that of 7.1 gram soybean meal 53\% CP on DM basis (Tikofsky and Harrison 2006). Results of the present study cleared that optigen incorporated in the CFM used for feeding of growing lambs by 0.9 and $1.8 \%$ had a positive effect on their productive performance and economical efficiency.

\section{REFERENCES}

1. Aljabary, E. M. and H. E. Kutaibani. 2013. The effect of using urea-molasses block and level of concentrate on performance and some carcass characteristics in Awessi lambs. J. Agric. Sci. Tikrite Univ, 13(2): 1813-1646.

2. AOAC. 2012. Official Methods of Analysis. 19th Ed., AOAC International, Gaithersburg, MD, USA.

3. Church, D.C. 1976. Digestive Physiology and Nutrition of Ruminants, vol. 1. Digestive Physiology 145. $2^{\text {nd }}$ Ed. 8 books, Corvallis, Oregan.

4. Eweedah, N.M.; M.I. Bassuony; A.M. Abd El-Razk and M.A. Abd-baky. 2016. Effect of supplementing different levels of optigen as a replacer to soybean on the steers performance. J. Agric. Res. kafrEl-sheikh Univ,J. Animal, Poultry and Fish Production, 42(2): 55-69.

5. Galina, M.A.; F. Perez-Gil; R.M.A. Ortiz; J.D. Hummel and R.E. Ørskov. 2003. Effect of slow release urea supplementation on fattening of steers fed sugar cane tops (Saccharum officinarum) and maize (Zea mays): ruminal fermentation, feed intake and digestibility. Livestock Production Science, 83:1-11.

6. Galo, E.; S.M. Emanuele; C.J. Sniffen; J. H. White and J.R. Knapp. 2003. Effects of a polymer-coated urea product on nitrogen metabolism in lactating Holstein dairy cattle. J. Dairy Sci. 86: 2154-2162. 
7. Harrison, G.A. and T. P. Karnezos. 2005. Can we improve the efficiency of nitrogen utilization in the lactating dairy cow? In: Recent Advances in Animal Nutrition in Australia. School of Rural Science and Agriculture, University of New England, 15: 146-154.

8. IBM SPSS Statistics 22 (2014). Statistical Package for the Social Science. Release 22. SPSS, Inc., Chicago, Illinois, USA.

9. Khan, M.I.; S. Ahmed; A. Rahman; F. Ahmed, A. Khalique; N.A. Ahmed; Z. Qadir; S. Umar; S. Ullah and B.E. Zam. 2015. Comparative efficacy of urea and slowrelease non-protein nitrogen on performance of Nili-Ravi Buffalo calves. Pakistan J. Zool., 47(4):1097-2015.

10. McDonald, P.; R.A. Edwads; F.D. Greenhalh and C.A. Morgan. 1995. Animal Nutrition. $5^{\text {th }}$ Ed., Prentices Hall, London, UK.

11. Mentz, A.M.; W.A. Van Niekerk; A. Hassen; R.J. Coertze and B.S. Gemeda. 2015. Effect of diets differing in rumen soluble nitrogen on utilization of poor-quality roughage by sheep. South African J. Anim. Sci., 45(5): 528-537.

12. Mould, F.L.; E.R. Ørskov and S.O. Mann. 1983. Associative effects of mixed feeds. Effects of type and level of supplementation and the influence of the rumen fluid $\mathrm{pH}$ on cellulolysisin vivo and dry matter digestion of various roughages. Anim. Feed Sci. Technol., 10: 15-30.

13. NRC. 1989. Nutrient Requirement of Dairy Cattle. $6^{\text {th }}$ Ed.,National Academy Press, Washington DC, USA.

14. Pinos-Rodríguez, J.M.; L.Y. Peña; S.S. González-Muñoz; R. Bárcena and A. Salem. 2010. Effects of a slow-release coated urea product on growth performance and ruminal fermentation in beef steers. Italian J. Anim. Sci., 9:16-19.

15. Satter, L. D. and R. E. Roffler. 1975. Nitrogen requirement and utilization in dairy cattle. J. Dairy Sci., 58:1219-1237.

16. Schneider, B.H. and W.P. Flatt. 1975. The Evaluation of Feeds Through Digestibility Experiments. The University of Georgia Press, Athens, Georgia, USA.

17. Tikofsky, J. and G.A. Harrison. 2006. Optigen II: improving the efficiency of nitrogen utilization in the dairy cow. In: Proceedings of Altech's $22^{\text {th }}$ Annual Symposium, Lexington, Kentucky, USA, pp. 373-380.

18. Van Keulen, J. and B.A. Young. 1977. Evaluation of acid-insoluble ash as a natural marker in ruminant digestibility studies. J. Anim. Sci., 44: 282-287.

19. Varlyakov, I.; V. Radev; T. Slavov and R. Mihaylov. 2015. Ethological and hematological indices in yearling sheep fed various dietary nitrogen sources. Agricultural science and Technology, 7(4): 423-430.

20. Warner, A.C.I. 1964. Production of volatile fatty acids in the rumen, methods of measurements. Nutr.Abst. and Rev., 34:339. 
تأثير الاستبدال الجزئي لكسب فول الصويا بالابتجين علي اداء الحملان النامية

سعيد احمد محمود'، محمود محمد بنداري'، نبيل محمد عويضه'، عبدالحميد عبدالحميد سرورج"

$$
\begin{aligned}
& \text { 1- قسم الانتاج الحيو اني - كليه الزر اعة - جامعه كفر الثيخ }
\end{aligned}
$$

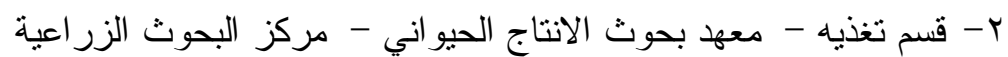

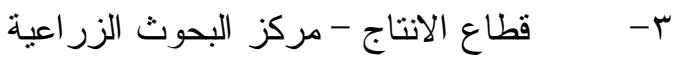

تهدف هذه الدراسة الي تقييم تأثير الاستبدال الجزئي لكسب فول الصويا بالابتجين كمصدر

بطئ لتحرر اليوريا في الكرش علي اداء الحملان النامية ومعاملات الهضم و الكفاءة الاقتصادية.

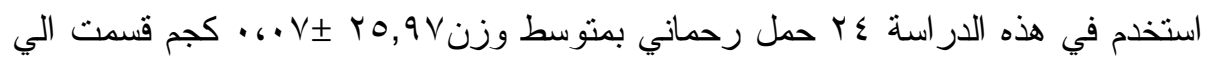

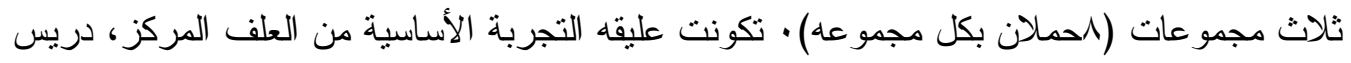

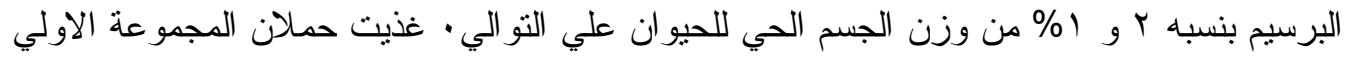

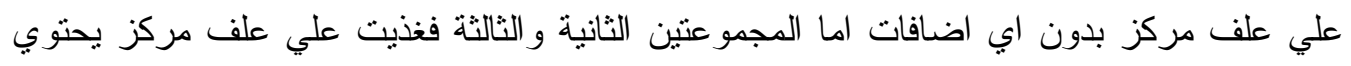

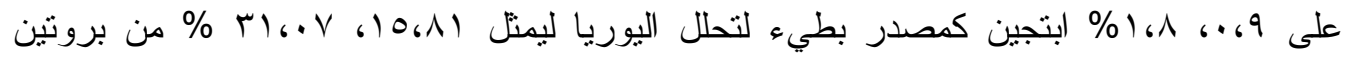
العلف المركز الثاني والثالث علي التو الي · وتم تقدير معاملات الهضم و القيم الغذائية للعلائق الثلاث المختبرة بالإضافة الي بعض صفات الكرش و الاداء الإنتاجي و الكفاءة الاقتصاديه. اوضحت النتائج تقارب التزكيب الكيماوي للعناصر الغذائية لمخلوط العلائق المختبرة. كانت العليقة الثانية هي الأعلى بالنسبة لمحتواها من المركبات الغذائية المهضومة و البروتين المهضوم و الطاقة المهضومة وسجلت العليقة الاولي اقل القيم بينما سجلت المجموعة الثالثة قيم وسطيه بفروق معنويه بين العلائق الثلاثة. اوضحت النتائج ايضا انه لا نوجد فروق معنويه بين العلائق الثلاثة بالنسبة لدرجة حموضة سائل الكرش وكذلك بالنسبة لوقت اخذ التذ العينات في حين سجلت الاحماض الدهنية الطيارة والامونيا فروق معنوية بين المعاملات وبين اوقات اخذ العينات . كانت المادة الجافة المأكولة منماثلة تقريبا في كل المعاملات بينما كانت الكميات المأكولة من المركبات الغذائية المهضومة والبرونين المهضوم والطاقة المهضومة في العليقة الثانية هي الأعلى وسجلت المجموعة الاولي اقل القيم في حين كانت القيم وسطية بالنسبة للعليقة الثالثة . حققت حملان المجموعة الثانية اعلي وزن حي ومعدل نمو كلى ويومي بفروق معنوية

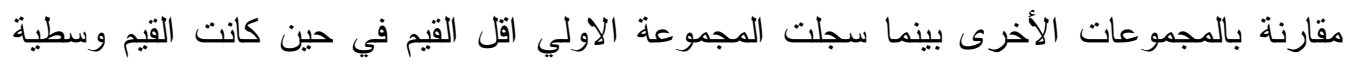

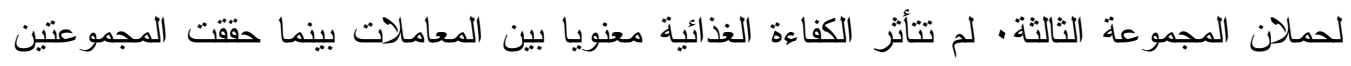
الثانية و الثالثة والتي غذيت علي مستويات مختلفة من الابتجين علي افضل قيم للكفاءة الاقتصادية بينما سجلت المجموعة الاولي اقل القيم. مدا سبق يتضح انه يمكن استخدام الابتجين بمستوى 9, · ،1.8\% في العلف المركز

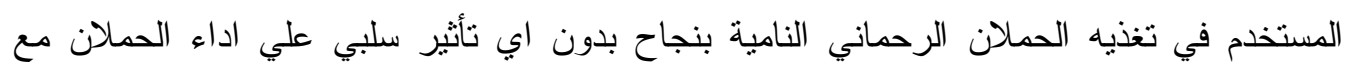
تحقيق افضل كفاءة اقتصادية. 